\title{
Recomendação para Extração e Análise de Testemunhos de Estruturas de Concreto
}

\section{Recomendaciones Técnicas}

\section{Paulo Helene}

https://doi.org/10.21041/AlconpatInternacional/RecTec/2020-09-testigosdeestructurasdeconcreto

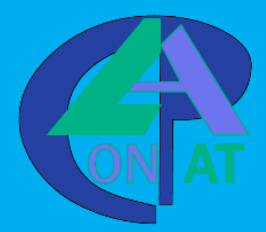

\section{ALCONPAT Internacional}

Asociación Latinoamericana de Control de Calidad, Patología y Recuperación de la Construcción

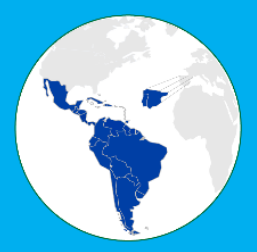




\section{$\mathrm{R}_{\text {ECOMENDACIÓN }} \mathrm{T}_{\text {ÉCNICA }}$}

\section{Editores}

\section{Pedro Garcés Terradillos}

Director de Recomendaciones Técnicas

Universidad de Alicante, España
Jorge Alberto Briceño Mena

Subdirector de Recomendaciones Técnicas

Cinvestav del IPN, Unidad Mérida, México

Recomendação para extração e análise de testemunhos de estruturas de concreto

DOI: https://doi.org/10.21041/AlconpatInternacional/RecTec/2020-09testigosdeestructurasdeconcreto

Recomendaciones de extracción e analisis de testigos de estructuras de hormigón

\section{Extraction recommendations and testimonials from concrete structures}

\section{Paulo Helene}

Diretor Presidente do Instituto Brasileiro do Concreto IBRACON. Diretor da PhD Engenharia. Prof. Titular da Escola Politécnica da Universidade de São Paulo EP.USP

São Paulo, Brasil. 


\section{Recomendación Técnica No. 9}

\section{SEGURANÇA DE ESTRUTURAS EXISTENTES \\ EXTRAÇÃO E ANÁLISE DE TESTEMUNHOS DE ESTRUTURAS DE CONCRETO: ENSAIOS, ANÁLISES E PROCEDIMENTOS}

\section{OBJETIVO}

Esta Recomendação Técnica estabelece os requisitos exigíveis para os processos de extração, preparo, ensaio e análise de testemunhos de estruturas de concreto com vistas à verificação da segurança de estruturas existentes, e trata especificamente dos procedimentos relativos à obtenção da resistência equivalente à resistência característica do concreto à compressão.

\section{ESCOPO}

Esta Norma estabelece os requisitos exigíveis para os processos de extração, preparo, ensaio e análise de testemunhos de estruturas de concreto com vistas à verificação da segurança de estruturas existentes, e trata especificamente dos procedimentos relativos à obtenção da resistência equivalente à resistência característica do concreto à compressão, referida a 28 dias de idade.

Os resultados obtidos pelo procedimento aqui estabelecido podem ser utilizados:

a) para aceitação definitiva do concreto de obras em construção, em casos de não conformidade da resistência à compressão do concreto obtida de corpos de prova moldados segundo procedimentos padronizados de controle de recebimento e aceitação;

b) para verificação da segurança estrutural em obras existentes, tendo em vista a execução de obras de retrofit, de reforma, de mudança de uso, de correção de obras submetidas a incêndio, acidentes, colapsos parciais e outras situações em que a resistência à compressão do concreto deva ser conhecida.

Este procedimento é aplicável à obtenção, preparação, ensaio, análise e orientação para verificação da segurança da estrutura a partir de testemunhos de concreto.

\section{GENERALIDADES}

\subsection{Campo de aplicação}

A extração de testemunhos de estruturas depende da aprovação prévia de um engenheiro responsável, seja ele o Construtor, o Projetista ou um Consultor. Nos casos controversos, que envolvam mais de um interveniente, a extração deve ser antecipadamente planejada em comum acordo entre as partes envolvidas (responsável pelo projeto estrutural, construtor responsável pela execução da obra, laboratório responsável pela extração dos testemunhos, responsável pela empresa de serviços de concretagem e consultores).

Sempre que for considerada necessária, a realização da extração de testemunhos deve ser precedida de estudos com base nos documentos disponíveis, a chamada anamnese (projetos de arquitetura e estrutural, memórias de cálculo, memoriais descritivos e outros), de forma a 
balizar a obtenção de informações consistentes e evitar extrações desnecessárias, que podem minorar a capacidade resistente da estrutura em avaliação.

Não existe uma maneira que consiga manter o concreto do testemunho sob as mesmas condições de cuidados padronizados que são exigíveis para os concretos destinados a corpos de prova de controle.
Este documento tem o escopo de orientar sobre as variáveis envolvidas na extração de testemunhos e recomendar as principais correções necessárias para uma equivalência confiável entre os resultados provenientes de um testemunho extraído da estrutura, com os resultados padronizados de corpos de prova moldados na boca da betoneira.

\subsection{Procedimento geral}

As recomendações presentes neste documento são aplicáveis quando houver necessidade de conhecer, por estimativa, a resistência à compressão do concreto em estruturas existentes.

Também são aplicáveis às estruturas novas e em execução, quando a resistência característica à compressão do concreto $f_{c k, e s t}$ de um certo lote, não atingir o $f_{c k}$ de projeto a partir dos critérios previstos para aceitação automática do concreto no estado endurecido. Neste caso, para evitar danos desnecessários à estrutura, antes da realização da extração, a segurança estrutural deve ser verificada a partir do valor da resistência característica à compressão estimada $f_{c k, e s t}$ calculada com base nos resultados efetivos obtidos nos ensaios dos corpos de prova moldados.

Feita esta verificação analítica, tem-se duas possibilidades:

a) O resultado dessa verificação é positivo: os requisitos de avaliação da segurança estrutural são considerados atendidos com a resistência disponível obtida de corpos de prova moldados, para a estrutura ou parte dela. Neste caso, não é necessária a realização de extrações de testemunhos e esse novo $f_{c k, \text { est }}$ deve constar da revisão de projeto para estes elementos e fazer parte dos arquivos de "as built";

b) O resultado dessa verificação é negativo: deve ser feito um planejamento da extração de testemunhos, considerando os critérios deste procedimento, em comum acordo com todas as partes envolvidas.

Para fins de verificação da segurança, sempre que possível, evitar extrair testemunhos de lajes, devido à grande variabilidade da resistência do concreto nesses elementos, e, à dificuldade de adensamento e cura. Quando houver necessidade de investigar a resistência do concreto em lajes, procurar fazer a extração do testemunho de alguma viga que tenha sido concretada com o concreto da mesma betonada do concreto usado na laje.

\section{EXTRAÇÃO DE TESTEMUNHOS}

\subsection{Equipamento de extração}

O equipamento utilizado para realizar a extração de testemunhos deve permitir a obtenção de amostras homogêneas e íntegras do concreto da estrutura.

O motor da extratora pode ser elétrico ou a gasolina / diesel / álcool. No caso de gasolina / diesel / álcool, evitar usar em locais fechados ou pouco ventilados.

Para extrair testemunhos cilíndricos, deve ser empregado um conjunto de extratora provido de cálice e coroa diamantada (zircônio), ou outro material abrasivo que seja equivalente e que possibilite realizar o corte dos testemunhos com as dimensões estabelecidas, sem danificar excessivamente a estrutura.

Durante o corte do concreto, o cálice e coroa do equipamento devem ser refrigerados com água fria corrente obtida por pressão ou gravidade com desnível mínimo de $1 \mathrm{~m}$, que também atua como lubrificante da perfuração. $\mathrm{O}$ equipamento 
deve estar devidamente calibrado e fixado à estrutura, visando minimizar vibrações para se obter o paralelismo entre as geratrizes dos testemunhos extraídos e evitar ondulações em sua superfície (vide Fig. 1).

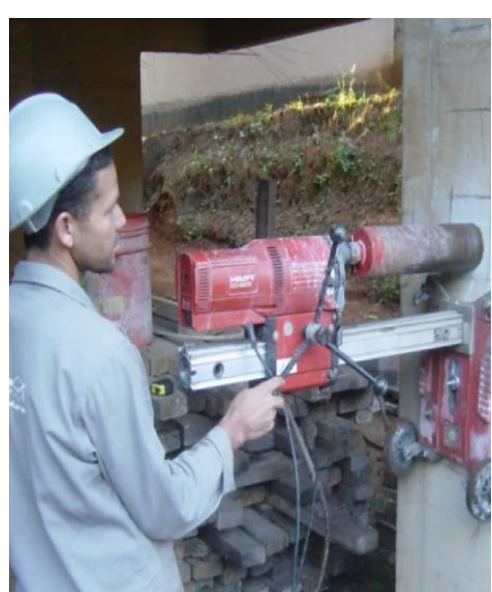
(a) equipamento de extração

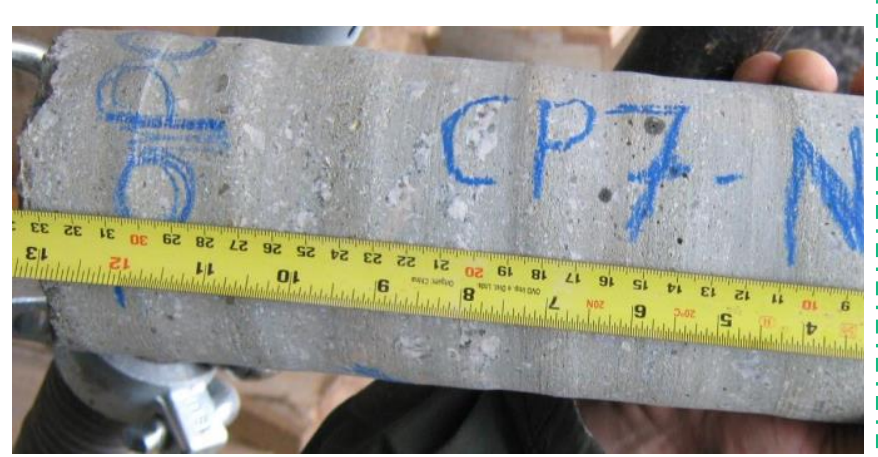

(b) testemunho

¡Figura 1. Exemplo de equipamento de extração adequadamente fixado à estrutura e de um testemunho com ondulações inadequadas resultantes de uma extração com vibrações.

Além disso, as armaduras deverão ser preservadas por meio da sua prévia e correta localização com uso de pacômetro de precisão, análise prévia do projeto de armação, e/ou, eventualmente, por prospecção com remoção parcial do cobrimento para identificar o real ou efetivo posicionamento das barras. Exemplos de insucesso neste procedimento podem ser visualizados na Fig. 2.

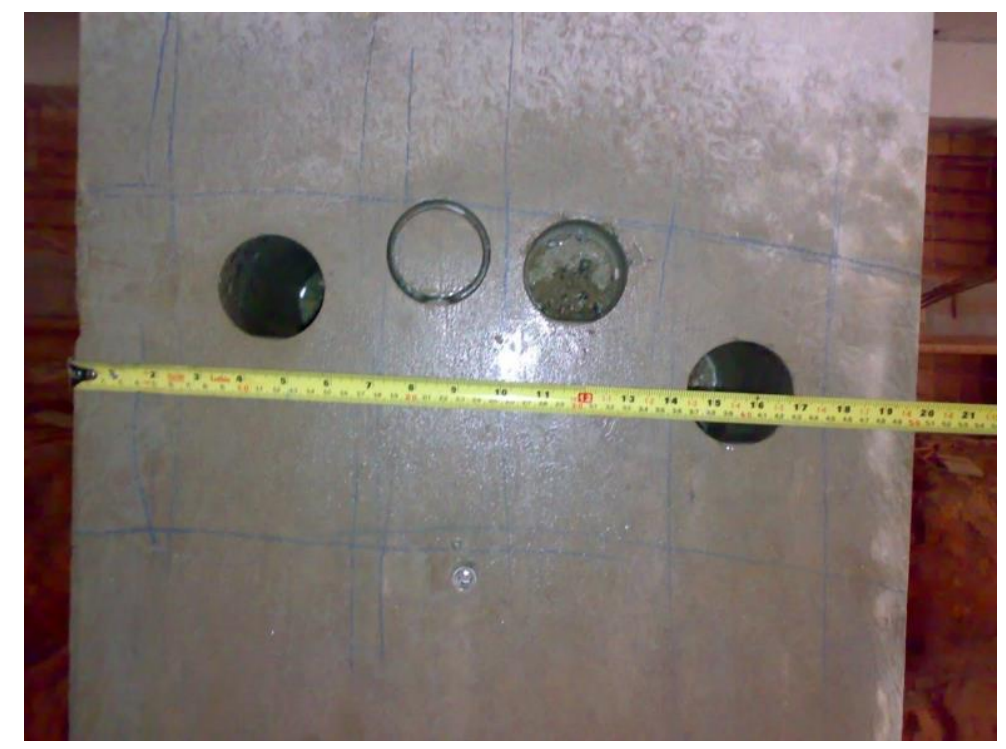

(a) tentativas de extração

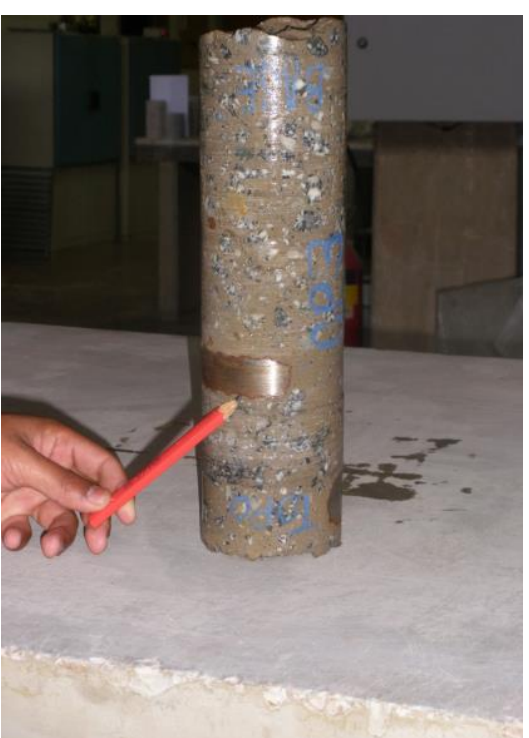

(b) armadura seccionada

Figura 2. Exemplos de extrações inadequadas realizadas sem o uso prévio de pacômetro e/ou prospecção da posição da armadura

É recomendável ainda que o concreto tenha resistência igual ou superior a $5 \mathrm{MPa}$ na ocasião da extração dos testemunhos. O concreto com resistências inferiores a esta podem ser afetados negativa e intensamente pela abrasão e agressividade dos esforços gerados pelo equipamento de extração, chamados de "efeito de broqueamento." 


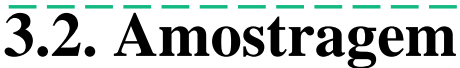

\subsubsection{Estruturas em execução}

O lote mínimo a ser analisado deve corresponder ao estabelecido na Tabela 1.

O lote deve abranger um volume de concreto que possibilite decidir sobre a segurança da estrutura, mas a extração de testemunhos deve ser tão reduzida quanto possível, para evitar maiores danos aos elementos estruturais analisados.

Tabela 1. Mapeamento da estrutura, formação de lotes e quantidade de testemunhos a serem extraídos

\begin{tabular}{|c|c|c|c|}
\hline $\begin{array}{c}\text { conhecimento } \\
\text { anterior }\end{array}$ & \multicolumn{2}{|c|}{ formação de lotes } & $\begin{array}{l}\text { quantidade mínima de } \\
\text { testemunhos por lote }\end{array}$ \\
\hline \multirow{2}{*}{$\begin{array}{c}\text { amostragem a } \\
100 \% \text { com } \\
\text { mapeamento } \\
\text { total }\end{array}$} & \multirow{2}{*}{$\begin{array}{l}\text { cada lote corresponde ao volume de uma } \\
\text { betonada }\end{array}$} & $\begin{array}{l}\text { aplicado em um } \\
\text { elemento estrutural }\end{array}$ & 1 \\
\hline & & $\begin{array}{l}\text { aplicado em mais de } 3 \\
\text { elementos estruturais }\end{array}$ & 3 \\
\hline \multirow{2}{*}{$\begin{array}{c}\text { desconhecimento } \\
\text { parcial ou total } \\
\text { do mapeamento }\end{array}$} & \multirow{2}{*}{$\begin{array}{l}\text { separar em lotes: um de pilares, outro de } \\
\text { vigas e cabeça de pilares, outro de lajes e } \\
\text { outro de blocos de fundações. Dentro de } \\
\text { cada grupo utilizar END, esclerometria e } \\
\text { ultrassom. Extrair testemunhos dos } \\
\text { elementos com índices END mais baixos. }\end{array}$} & até $8 \mathrm{~m}^{3}$ & 3 \\
\hline & & $\begin{array}{c}\text { maior que } 8 \mathrm{~m}^{3} \text { e menor } \\
\text { que } 50 \mathrm{~m}^{3}\end{array}$ & 6 \\
\hline
\end{tabular}

Os lotes não identificados por mapeamento durante a concretagem (lotes sem rastreabilidade) podem ser mapeados por meio de ensaios não destrutivos. Pode ser utilizado qualquer procedimento confiável, sendo adequado empregar a avaliação da dureza superficial pelo esclerômetro de reflexão ou a determinação da velocidade de propagação de onda ultrassônica.

Os métodos não destrutivos, END, também podem ser utilizados para comprovar a homogeneidade do concreto em um lote identificado por mapeamento. Os métodos não destrutivos não devem ser utilizados para fornecer direta e isoladamente a resistência à compressão do concreto para fins de verificação da segurança.

Diferentes alturas e locais de ensaio, diferentes texturas superficiais (devido a fôrmas), diferentes taxas de armadura, pequenos cobrimentos, ou até mesmo diferenças na umidade interna do concreto podem alterar os resultados de avaliações realizadas exclusivamente com ensaios não destrutivos. Portanto, todos os ensaios devem ser realizados por equipe competente, pois existem fatores que podem confundir as análises.

Evitar extrair mais de um testemunho do mesmo pilar. Se for de fato necessário, observar que as extrações sejam realizadas numa mesma vertical e numa mesma face.
Sempre que possível, aproveitar neste planejamento os lotes utilizados por ocasião do controle da resistência a partir de corpos de prova moldados (conceito de mapeamento ou rastreabilidade).

É recomendável que sejam extraídos pelo menos 3 testemunhos de um lote a ser verificado, sendo possível, no entanto, fazer a verificação de um único pilar ou uma única viga através de um só testemunho.

\subsubsection{Estruturas existentes}

Os requisitos mínimos relativos ao mapeamento, à formação de lotes e à quantidade de testemunhos a serem extraídos também estão estabelecidos na Tabela 1.

No caso de estruturas sem histórico do controle de recebimento e aceitação da resistência do concreto, estas devem ser divididas em lotes identificados em função da importância dos elementos estruturais que as compõem, e da homogeneidade do concreto, que pode ser avaliada, previamente, por meio de ensaios não destrutivos (END), tipo esclerometria e ultrassom.

O local para a extração de testemunhos em uma estrutura deve ser determinado por consenso entre os intervenientes, de forma a reduzir os riscos de extração em locais inadequados.

Devem ser obedecidas as seguintes condições: 
1. A estrutura deve ser dividida em lotes, sendo que um pilar, uma viga ou uma laje, pode ser considerado como um lote;

2. Os testemunhos devem ser extraídos a uma distância maior ou igual ao seu diâmetro com relação às juntas de concretagem, às bordas das perfurações ou às bordas do elemento estrutural, ou mesmo entre testemunhos;

3. Não podem ser cortadas armaduras principais; o seccionamento de estribos, em alguns casos, pode ser permitido. Para evitar este risco, deve ser usado um detector de metais (pacômetro) ou procedimento equivalente, ou prospecção por retirada do cobrimento;

4. Em pilares, paredes e elementos verticais passíveis de sofrerem com maior intensidade o fenômeno de exsudação e de segregação, deve-se realizar a extração dos testemunhos a pelo menos $50 \mathrm{~cm}$ dos limites superior e inferior da etapa de concretagem (junta fria de concretagem) do elemento estrutural e acima da região de traspasse das barras longitudinais;

5. Caso seja necessário estimar a resistência do concreto no topo do pilar, quando de concretagens realizadas em duas etapas, em conjunto com vigas e lajes, recomendase que a extração seja realizada na viga contigua, desde que contenha o "mesmo" concreto;

6. Quando da extração de mais de um testemunho no mesmo pilar, estes devem ser retirados na mesma face e prumada, obedecendo a distância mínima entre furos;

7. Recomenda-se que a redução da seção transversal de um pilar pelo furo deixado pelo testemunho extraído seja sempre inferior a $10 \%$ da seção transversal do pilar. Reduções de seção superiores a $10 \%$ devem ser discutidas e autorizadas pelo projetista estrutural;

8. A segurança estrutural deve ser assegurada em todas as etapas (antes, durante e após a extração) e, quando necessário, com o uso de escoramentos temporários;

9. Não extrair testemunhos com fissuras nem em fissuras, a não ser que o objetivo seja conhecer a fissura, ou seja, para resistência do concreto do testemunho, este deve estar íntegro;
10. No caso de testemunhos de estacas, estes devem ser íntegros e retirados do centro da estaca e a profundidades superiores à cota de arrasamento (de concreto íntegro). Podem ser extraídos testemunhos para outras finalidades, em qualquer posição, como para verificar a contaminação com solo, porosidade e exsudação, porém estes não servem ao propósito de verificação da resistência à compressão do concreto.

\subsubsection{Escolha das dimensões dos testemunhos a serem extraídos}

O diâmetro de um testemunho cilíndrico utilizado para determinar a resistência à compressão deve ser de, pelo menos, três vezes a dimensão máxima característica do agregado graúdo contido no concreto e preferencialmente maior ou igual a $75 \mathrm{~mm}$.

A relação altura/diâmetro dos testemunhos cilíndricos deve ser a mais próxima possível de dois, após cortes e preparo, obedecendo sempre a condição de $1 \leq \mathrm{h} / \mathrm{d} \leq 2$, onde $\mathrm{h}$ é a altura do testemunho medida após preparo dos topos, e d é o diâmetro do testemunho.

Em casos específicos, podem ser utilizados testemunhos de diâmetro menor que $75 \mathrm{~mm}$ e igual ou maior que $25 \mathrm{~mm}$, desde que acordado entre as partes envolvidas. Nestes casos, o número mínimo de testemunhos deve ser o dobro do estabelecido na Tabela 1 .

\subsubsection{Corte e retirada dos testemunhos}

Por razões éticas, as operações de extração e rompimento de testemunhos deverão ser realizadas por Laboratório distinto daquele que executou os ensaios de controle de recebimento e aceitação do concreto, moldagem e/ou rompimento dos corpos de prova, e sempre devem ter acompanhamento técnico das partes envolvidas.

A extração deve ser precedida de uma verificação in loco do posicionamento das armaduras, concomitantemente com o estudo do projeto estrutural. Caso ocorra o corte involuntário de armaduras, estas devem ser repostas com procedimento adequado de traspasse, ou solda, em conformidade com o projetista estrutural e as normas em vigor.

A operação de extração deve ser realizada considerando as recomendações gerais de uso da 
aparelhagem previstas pelo fabricante do equipamento de extração.

A retirada do testemunho após o corte deve ser feita de forma que se provoque um esforço ortogonal ao eixo do testemunho em seu topo, rompendo o concreto em sua base. Este esforço pode ser provocado pela introdução de uma ferramenta nas interfaces entre o testemunho e o orifício, em posições alternadas, usando a ferramenta como alavanca, com o necessário cuidado para não romper as bordas do testemunho.

Deve-se evitar a extração de testemunhos em elementos estruturais que foram submetidos a algum tipo de reforço anteriormente, esse elemento, em geral, não representa a real resistência do concreto da estrutura em questão.

\subsubsection{Integridade dos testemunhos}

Os testemunhos devem ser íntegros, isentos de fissuras, segregação, ondulações e não podem conter materiais estranhos ao concreto, como pedaços de madeira e de armaduras. Testemunhos que apresentem defeitos como os citados devem ser descartados.

Sempre que possível, devem ser eliminados os eventuais pedaços de barras de armadura presentes nos testemunhos destinados ao ensaio de compressão, ou seja, buscar, no testemunho, cortar fora os trechos com eventual armadura, de modo a resultar um testemunho íntegro e dentro dos limites de dimensões toleradas.

Para comprovação da inexistência de corpos estranhos dentro dos testemunhos, pode ser utilizado ensaio não destrutivo tipo ultrassom, além da observação visual cuidadosa antes e após ruptura e desagregação do testemunho.

Quando houver comprovação de heterogeneidade do concreto e existência de alterações internas nos testemunhos (fissuras e descontinuidades), as quais devem ser identificadas e relatadas, os resultados destes testemunhos devem ser descartados para fins de resistência, mas podem ser considerados para fins de avaliação da qualidade da execução.

Da mesma forma, testemunhos que apresentam alterações internas (fissuras e descontinuidades) e concreto heterogêneo indicam deficiências nas operações de concretagem da estrutura, que devem ser identificadas e relatadas, e podem servir ao objetivo de verificar a qualidade da execução, mas não servem ao propósito de medir a resistência potencial do concreto à compressão.

Após a retirada dos testemunhos, estes devem ser identificados, mantidos na temperatura ambiente e transportados ao laboratório de ensaio com cuidado, preferencialmente em caixas de areia ou serragem, ou pallets, para evitar choques.

No laboratório proceder de imediato à preparação dos topos através de corte, preferencialmente com equipamento refrigerado e lubrificado a água fria e limpa.

Uma vez que os testemunhos estejam "preparados", cortados, identificados e com topos polidos, estes devem ser armazenados a seco no ambiente do Laboratório ou sob água ou em câmara úmida.

Quando se trata de concreto proveniente de ambiente seco os testemunhos devem ser mantidos no ambiente de laboratório por $48 \mathrm{~h}$, e ensaiados a seco.

Quando se trata de concreto proveniente de ambiente úmido os testemunhos devem ser mantidos submersos em água, em temperatura controlada, ou na câmara úmida por, no mínimo $24 \mathrm{~h}$, e devem ser rompidos úmidos ou saturados.

\subsection{Documentaçã̃o do procedimento de extração}

Cabe ao profissional responsável pela extração dos testemunhos:

a) documentar com fotos o processo de extração, identificando:

- O testemunho extraído;

- O posicionamento dos furos no elemento estrutural;

- Registrar e fotografar sinais de eventual segregação ou fissuras na região da extração.

- fazer um croqui de localização das extrações, identificando:

- O elemento estrutural;

- A distância entre furos, no caso de haver mais de um furo por elemento estrutural;

- A locação do furo em planta e elevação. 


\subsection{Reparo dos locais de extração dos testemunhos}

A extração não pode prejudicar o desempenho e a durabilidade da estrutura. A reconstituição do local da extração deve restabelecer as condições de segurança, geométricas e estéticas iniciais da estrutura. Para tanto, o local da extração deve ser preenchido com concreto compatível com o especificado para o elemento estrutural e devem ser tomados os cuidados necessários para que o procedimento de reparo seja eficiente.

No caso da armadura ter sido seccionada pelo processo de extração, é necessário recuperar o elemento estrutural afetado por meio da emenda das barras de aço por traspasse ou por solda.

Para garantir o desempenho estrutural e a durabilidade esperada da estrutura, deve-se realizar o fechamento e a recomposição adequada de todos os locais onde foram efetuadas a extrações de testemunhos de concreto por meio da reabilitação da área afetada pelo furo.

Sempre que possível, o reparo do elemento estrutural, ou seja, o fechamento do óculo ou furo da extração, deve ser feito o mais breve possível, de acordo com as recomendações a seguir:

\subsubsection{Preparo e limpeza de substrato}

A limpeza do furo deve eliminar detritos, poeiras e afins que possam atrapalhar o desempenho mecânico ou a durabilidade final do elemento estrutural reparado.

A seguir, deve-se efetuar o lixamento com auxílio de lixa apropriada para concreto, ou escova de aço giratória, de modo a promover rugosidade no interior das paredes do furo para melhorar a aderência do concreto velho com o concreto a ser aplicado no fechamento do furo.

Antes de iniciar o preenchimento do furo, sua superfície interna deve estar limpa e previamente saturada com água, até a condição de "saturado superfície seca", visto que esta condição propicia melhor aderência entre o concreto existente com o concreto novo de preenchimento.

\subsubsection{Preenchimento do furo}

Para recomposição dos furos horizontais de testemunhos extraídos, recomenda-se a utilização do procedimento de socamento de argamassa seca, também conhecido como "dry pack".

Podem ser utilizadas argamassas preparadas na obra, ou argamassas pré-dosadas, de linha comercial / industrial, que atendam os requisitos de desempenho superiores às do concreto original da estrutura.

O procedimento de recomposição consiste nas seguintes etapas:

a) dosagem da argamassa seca na própria obra: a base de cimento Portland e agregado miúdo na proporção em massa de uma parte de cimento para uma de agregado miúdo. A água total da mistura deve equivaler a, no máximo, $25 \%$ da massa de cimento, de modo a se obter uma argamassa de consistência quase seca, e com trabalhabilidade de "massa de moldar", adequada para o seu manuseio; ou,

b) argamassa industrializada a base de cimento Portland, com polímeros e preferencialmente com aditivos compensadores de retração, com resistência compatível com a da estrutura. A água total da mistura deve seguir as especificações do fabricante, e equivaler a cerca de $10 \%$ da massa da argamassa, de modo a se obter uma argamassa de consistência quase seca, e com trabalhabilidade de "massa de moldar", adequada para o seu manuseio;

c) a mistura, de qualquer uma das argamassas, deve ser efetuada em balde metálico ou plástico, com fundo plano, com equipamento de mistura dotado de hélices helicoidas, ou qualquer outro equipamento de mistura forçada. Não se permite o uso de betoneiras estacionárias, simples de obra, de eixo inclinado com mistura por "tombo", pois este procedimento de mistura não consegue misturar adequadamente;

d) com auxílio das mãos devidamente protegidas por luvas de borracha, e, após a dosagem e mistura da argamassa quase seca, em quantidade suficiente para se preencher o furo, deve-se realizar o preenchimento deste em camadas alternadas, sendo cada camada com espessura menor que $5 \mathrm{~cm}$ de argamassa;

e) na sequência escolher agregados graúdos limpos, lavados e saturados, inserindo-os na argamassa seca que se encontra no fundo do óculo;

f) socar essas "pedras" individualmente de modo a obter uma camada de "concreto" resultante da mistura da argamassa seca 
"preenchida" com o agregado graúdo socado para preencher toda seção do furo;

g) depois de colocadas as duas primeiras camadas de argamassa e agregado graúdo, com auxílio de um soquete cilíndrico deve-se socar as camadas, de modo que a camada de agregado graúdo seja empurrada para dentro da camada de argamassa;

h) repetir este procedimento até que todo o furo seja preenchido, conforme ilustrado na Fig. 3.

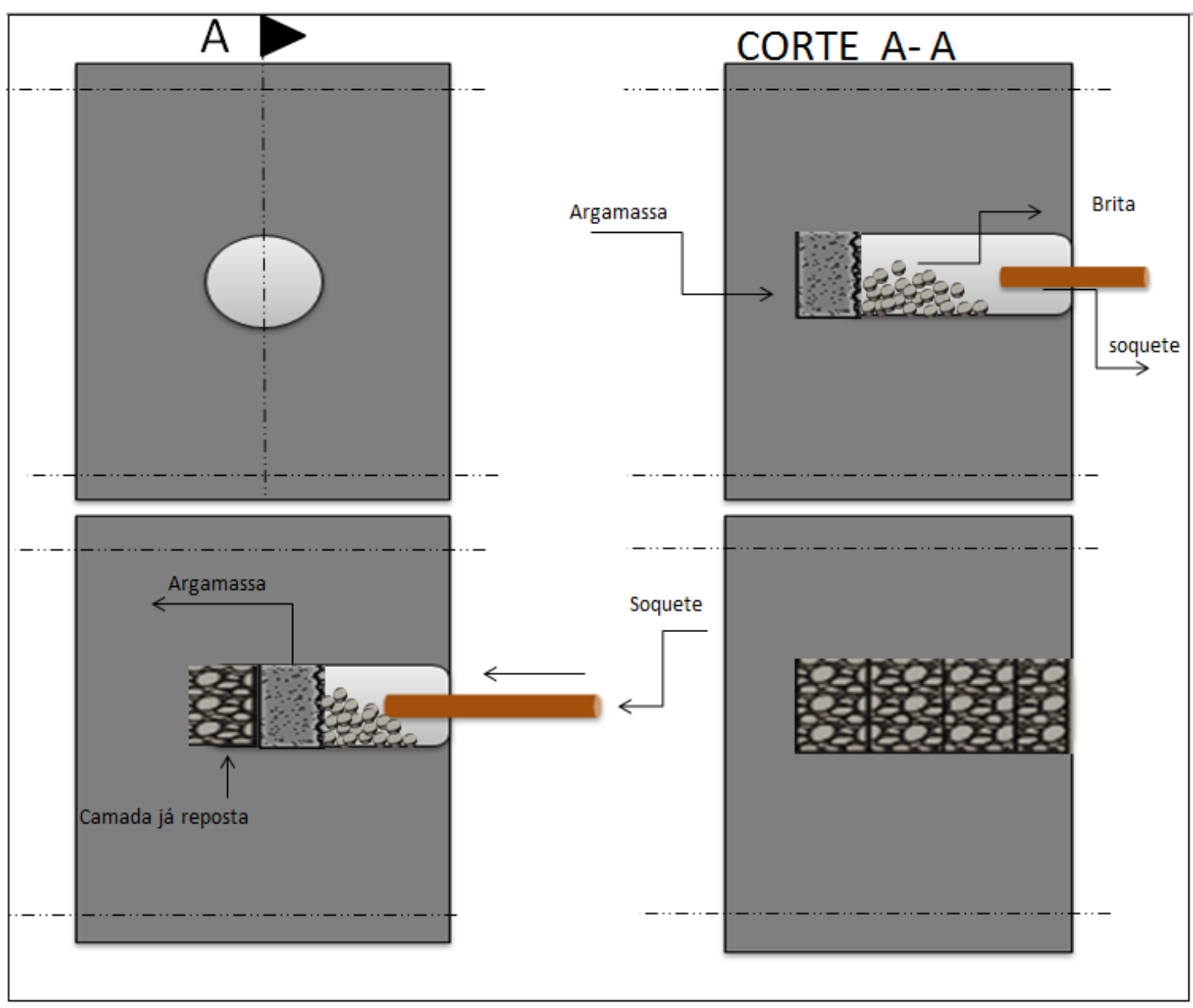

Figura 3. Ilustração, da reposição de concreto, nos locais da extração dos testemunhos

Após a última camada, deve ser realizado o acabamento com auxílio da desempenadeira de madeira, uniformizando o reparo com a face do elemento estrutural.

Após uniformização do reparo, deve-se promover a sua cura, mantida por 3 dias, por meio da aspersão de água e utilização de espuma ou manta, por exemplo, que ajudam a manter a superfície do reparo úmida, evitando assim o destacamento das bordas.

No caso de furos de extrações realizadas na direção vertical, podem ser utilizados em seu preenchimento graute industrializado ou concreto autoadensável, ambos com aditivos compensadores de retração. Nestes casos, recomenda-se que após o preenchimento total do furo, o material seja extravasado para se evitar a exsudação e destacamento das bordas do reparo. Para os casos de furos passantes que atravessem o elemento estrutural, recomenda-se a utilização de fôrmas, se necessário do tipo cachimbo, para auxiliar seu preenchimento.

\section{Controle de qualidade}

Para garantir que o reparo do local da extração atenda os requisitos do projeto, é recomendável o acompanhamento do desempenho da argamassa seca utilizada no reparo com ensaios normalizados e moldagem, conforme com ASTM C 192 (ABNT NBR 5738), e ensaio de corpos de prova, segundo a ASTM C 39 (ABNT NBR 5739). 
Assim que os testemunhos chegarem ao Laboratório, estes devem ser cortados utilizando serra diamantada dotada de refrigeração à água, ou equipamento equivalente, para:

a. correção da relação altura/diâmetro, que deve estar entre $\mathrm{h} / \mathrm{d}=1 \mathrm{e} \mathrm{h} / \mathrm{d}=2$;

b. retirada de materiais estranhos, tais como madeira, barra de aço, bicheiras, quando for o caso;

c. obtenção de paralelismo entre os planos dos topos e sua ortogonalidade com as geratrizes do cilindro.

A massa específica ao natural, seca ou saturada dos testemunhos sempre deve ser medida e registrada.

Os topos devem ser preparados como previsto a seguir:

1. quando os topos dos testemunhos forem regularizados por retífica (lixamento ou polimento) devem obedecer às prescrições do método ASTM C 39 (ABNT NBR 5739);

2. a determinação da massa do testemunho deve ser feita após o corte do testemunho e retífica dos topos, mas sempre antes de um eventual capeamento. A massa dos testemunhos deve ser determinada por meio de balança com resolução mínima de $1 \mathrm{~g}$;

3. quando os topos dos testemunhos forem regularizados por capeamento, devem obedecer às prescrições do método ASTM C 39 (ABNT NBR 5739);

4. o diâmetro utilizado para o cálculo da área da seção transversal deve ser a média de duas medidas ortogonalmente opostas, realizadas na metade da altura do testemunho, com exatidão de $0,1 \mathrm{~mm}$;

5. a altura do testemunho deve ser a média de três determinações, realizadas com exatidão de $0,1 \mathrm{~mm}$, em geratrizes aproximadamente equidistantes $120^{\circ}$ entre si. Essas medidas devem ser tomadas após a retífica dos topos;

6. o volume dos testemunhos deve ser calculado a partir das medidas médias do diâmetro e da altura;
7. calcular a massa específica do concreto com aproximação de $1 \mathrm{~kg} / \mathrm{m}^{3}$, dividindo-se a massa do testemunho por seu volume;

8. é possível analisar a qualidade do processo de vibração (adensamento) do concreto pela diferença entre a massa específica do testemunho saturado e a massa específica do concreto fresco e adensado medida quando do recebimento do concreto fresco, ou informada a partir do estudo de dosagem;

9. caso essa diferença seja significativa (por exemplo, > $50 \mathrm{~kg} / \mathrm{m}^{3}$ ), pode-se inferir que o concreto não foi adensado adequadamente, denotando deficiências na qualidade da execução da estrutura, que podem alterar significativamente a resistência à compressão do concreto;

10. nestes casos, convêm que sejam realizados ensaios complementares, como a determinação da porosidade, do volume ou índice de vazios e da massa específica do concreto, conforme o método ASTM C 642 (ABNT NBR 9778), pois pesquisas têm demonstrado que o acréscimo de $1 \%$ no índice ou volume de vazios por deficiência de adensamento, é responsável pela redução de $5 \%$ a $7 \%$ nos valores de resistência à compressão do concreto.

\subsubsection{Condições de umidade}

Quando o concreto da região da estrutura que está sendo examinada não estiver em contato com água, os testemunhos, depois de preparados para ensaio, devem ser mantidos expostos ao ar, em ambiente de laboratório por, no mínimo, 48 $\mathrm{h}$, dentro do intervalo de temperatura especificado na ASTM C 192 e ASTM C 39, e ensaiados secos, no estado de equilíbrio que se encontrem.

Quando o concreto da região da estrutura que está sendo examinada estiver em contato com água, os testemunhos devem ser acondicionados em tanque de cura ou câmara úmida de acordo com ASTM C 192 e ASTM C 39, por no mínimo $24 \mathrm{~h}$, sendo rompidos saturados. 


\subsection{Determinação da resistência à compressão}

\subsubsection{Procedimentos}

Os testemunhos devem ser ensaiados de acordo com o estabelecido no método ASTM C 39 (ABNT NBR 5739), sendo determinada sua resistência de ruptura à compressão axial.

Testemunhos que não atendam os requisitos de homogeneidade e integridade definidos neste documento não podem ser ensaiados, pois não devem ser considerados para fins de avaliação da resistência à compressão do concreto. $\mathrm{O}$ fato deve ser registrado no relatório do ensaio.

Cada testemunho deve ser detalhadamente observado antes e após a ruptura, sendo carregado na prensa até sua total desagregação. Caso a configuração de ruptura seja semelhante aos exemplos das Fig. 2, 3, 4 e 5, estas devem ser anotadas e documentadas com fotos e descartados para fins de medida da resistência à compressão do concreto. $\mathrm{O}$ resultado de resistência de testemunhos, que apresentam defeitos, falhas e evidências de erros nos arremates de seus topos e bases (vide Fig. 4, Fig. 5, Fig. 6 e Fig. 7), deverá ser descartado (ASTM C 39 item 7.10.12).

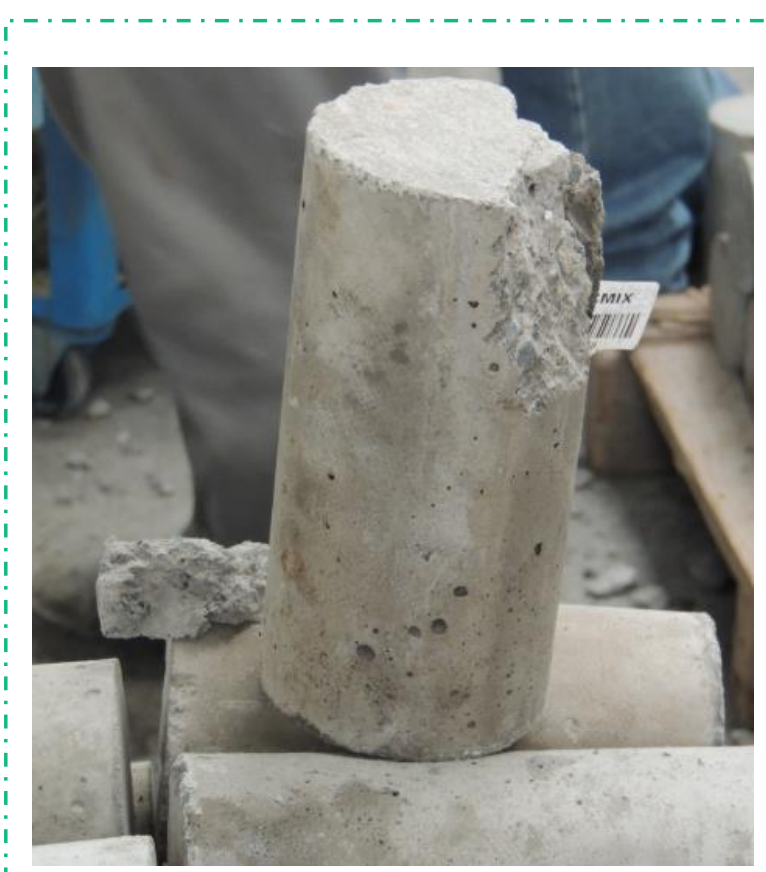

Figura 4. Ruptura no topo por erro de ensaio!

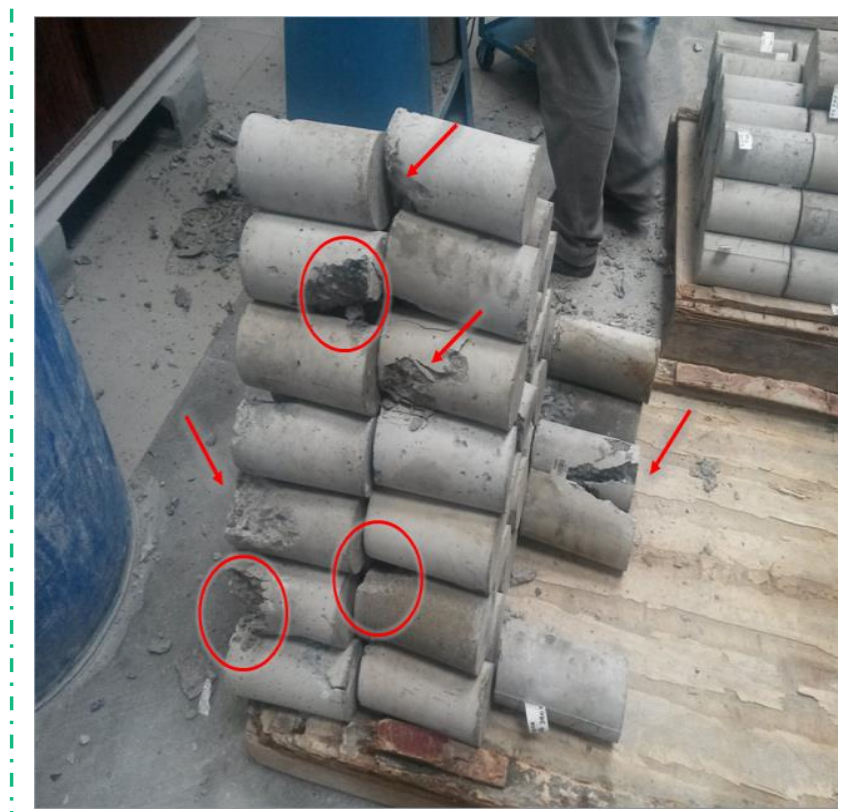

Figura 5. Ruptura no topo por erro de ensaio
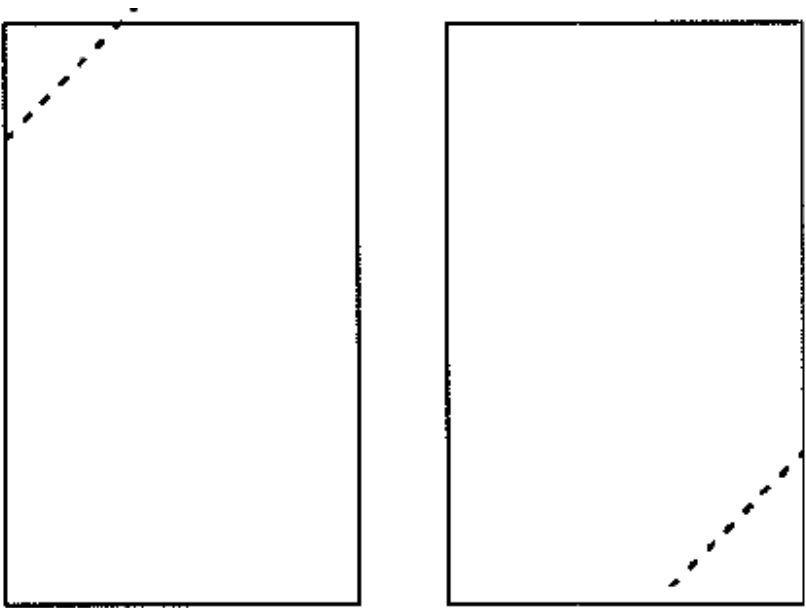

Figura 6. Fraturas no topo elou na base abaixo do capeamento (Fonte: ABNT NBR 7680-1:2015)

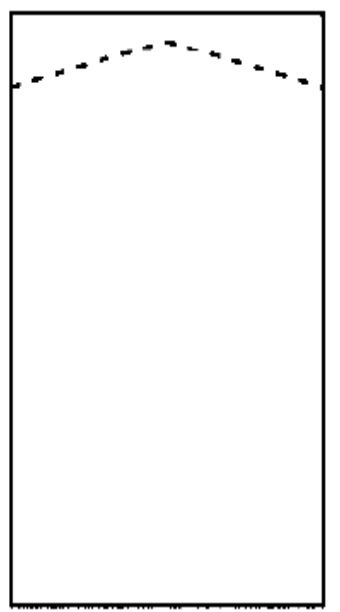

Figura 7. Fraturas no topo elou base abaixo do capeamento (Fonte: ABNT NBR 7680$1: 2015)$ 
Os resultados obtidos diretamente do ensaio de resistência à compressão axial dos testemunhos extraídos devem ser identificados por $f_{c i, l a b, j}$ onde:

$f_{c i, l a b, j}=$ resistência à compressão do testemunho de concreto (em MPa), identificado por $i$ (numeral de 1 a $n$ ), obtida diretamente do ensaio no laboratório, na idade $j$ (em dias).

\subsubsection{Relatório da extração e do ensaio}

O relatório da extração e do ensaio deve conter as seguintes informações;

1. croqui da localização dos testemunhos nos elementos da estrutura;

2. data da extração;

3. data do ensaio de compressão axial;

4. dimensões do testemunho;
5. período de tempo (duração) e condição de sazonamento do testemunho no Laboratório, até o momento do ensaio;

6. fotos do processo de extração;

7. massa do testemunho seco ou saturado;

8. massa específica dos testemunhos secos ou saturados;

9. massa específica do concreto fresco e adensado, quando for conhecida;

10. fotos dos testemunhos antes e após ensaiados a compressão;

11. registro de descontinuidades (fissuras, ninhos de concretagem) ou materiais estranhos (madeira, aço) no testemunho;

12. resultado de resistência à compressão axial obtido da ruptura de cada testemunho extraído $\left(f_{c i, l a b, j}\right)$;

13. resolução da escala da prensa;

14. data de aferição e calibragem da prensa.

\section{PROCESSAMENTO DOS RESULTADOS}

\subsection{Conceitos}

Para a aceitação do concreto a partir dos resultados de testemunhos extraídos de uma estrutura, é necessário estabelecer critérios de comparação que corrijam as interferências negativas dos processos e procedimentos construtivos (Construtora) e de extração e ensaio (Laboratório).

Os corpos de prova moldados durante o controle tecnológico do concreto são submetidos aos melhores procedimentos de moldagem, cura e ensaio e fornecem a resistência máxima potencial do concreto, na boca da betoneira. Qualquer deficiência de obra sempre reduz a resistência potencial, ou seja, não há procedimento de obra ou de ensaio que aumente resistência, ou seja, na melhor das hipóteses serão iguais.

As principais diferenças entre corpos de prova moldados e testemunhos a serem consideradas nos coeficientes de correção, são as seguintes:

a) as dimensões dos testemunhos e de corpos de prova moldados podem não ser as mesmas;

b) o testemunho reflete eventuais deficiências do processo de execução (lançamento, adensamento, concretagem e cura) e o corpo de prova não;

c) o processo de extração gera o que se denomina de "efeito deletério de broqueamento", que ocorre em todos os casos de extração;

d) a direção da moldagem dos corpos de prova é sempre a mesma da direção de aplicação da carga no ensaio de ruptura, ou seja, vertical a favor da gravidade. Em testemunhos extraídos, a relação entre a direção do lançamento do concreto (vertical) e a direção da aplicação da carga no ensaio de ruptura (normal à de extração) pode não ser a mesma. No caso de testemunhos extraídos de pilares, por exemplo, a aplicação da carga (no ensaio) é ortogonal à direção do lançamento do concreto (na estrutura), o que implica na correção dos resultados do ensaio, devido à orientação da rede capilar ser diferente no testemunho em cada um dos sentidos ou direção de extração;

e) na moldagem, o corpo de prova é adensado de forma padronizada, enérgica e homogênea, o que nem sempre ocorre em todos os pontos da 
estrutura, havendo diferenças de adensamento entre os dois;

f) os resultados dos testemunhos são mais representativos da resistência real ou efetiva da estrutura, mas não é esta a resistência que se usa para a verificação estrutural. A verificação estrutural usa $o$ $\boldsymbol{f}_{\boldsymbol{c k} \text {,est }}$ que é a resistência potencial do concreto na "boca da betoneira", medida através de corpos de prova moldados;

g) a retirada precoce de escoramentos, em elementos submetidos a flexão, gera microfissuração no concreto, o que não se verifica em corpos de prova moldados e curados em condições ideais de laboratório durante a preparação para o ensaio;

h) há locais na estrutura onde há risco de exsudação e de segregação do concreto por problemas de lançamento ou adensamento inadequado, risco este que não ocorre na moldagem do corpo de prova padrão;

i) a cura dos corpos de prova moldados é realizada em câmara úmida ou por imersão em água e mantidos à temperatura controlada. $\mathrm{O}$ concreto dos testemunhos pode ter sido retirado de um elemento estrutural que não recebeu cura adequada após a concretagem e que também foi submetido a um regime de temperatura diferente do ideal de laboratório;

j) a idade da ruptura dos corpos de prova moldados e dos testemunhos extraídos pode ser diferente, e testemunhos rompidos em idades mais avançadas podem apresentar resistência mais elevada, que a do concreto ensaiado a 28 dias, por efeito da maior hidratação do cimento;

k) o regime de cura, temperatura e principalmente de carga atuante pode ser muito diferente no concreto do testemunho em relação ao concreto do corpo de prova, que sempre está relaxado, sem carga e num ambiente ideal. Portanto, o concreto do testemunho pode apresentar resistência inferior ao do corpo de prova por efeito da chamada carga de longa duração.

\subsection{Coeficientes de correção}

\subsubsection{Generalidades}

Os coeficientes previstos neste documento, quando aplicáveis, devem ser utilizados para corrigir as interferências nos resultados obtidos nos ensaios de resistência de testemunhos extraídos de estruturas devido a diversos fatores e aplicam-se aos resultados de testemunhos de estruturas de concreto de massa específica normal, compreendida no intervalo de 2.000 $\mathrm{kg} / \mathrm{m}^{3}$ a $2.800 \mathrm{~kg} / \mathrm{m}^{3}$, com resistências características à compressão no intervalo de 8 $\mathrm{MPa}$ a $90 \mathrm{MPa}$.

A resistência à compressão do concreto, obtida a partir de testemunhos, deve ser obtida através do uso de coeficientes de correção, aplicáveis ou não, segundo cada situação específica, de acordo com a expressão:

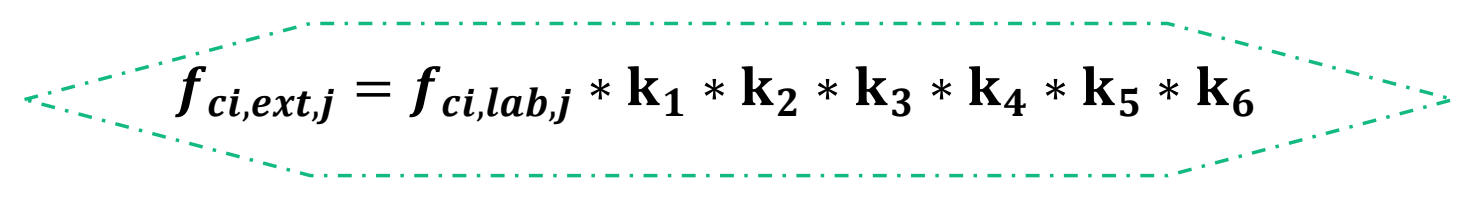

\subsubsection{Relação $h / d$ (k1)}

Quando a relação $\mathrm{h} / \mathrm{d}=2$ não se verifica, o resultado de resistência à compressão do testemunho deve ser corrigido, sendo utilizado o coeficiente definido na Tabela 2. Esta correção deve ser informada no relatório de ensaio. Para valores da relação altura/diâmetro compreendidos entre os constantes na Tabela 2, os coeficientes de correção podem ser obtidos por interpolação linear.

$\mathrm{O}$ coeficiente de correção $\mathrm{k}_{1}$ deve ser aplicado a todos os casos. 
Tabela 2. Coeficiente de correção da relação $\mathrm{h} / \mathrm{d}$, valores de $\mathrm{k}_{1}$

\begin{tabular}{c|c}
\hline Relação h/d & $\begin{array}{c}\text { Coeficiente de } \\
\text { correção, k } \mathbf{~}\end{array}$ \\
\hline 2,00 & 1,00 \\
\hline 1,75 & 0,98 \\
\hline 1,50 & 0,96 \\
\hline 1,25 & 0,93 \\
\hline 1,00 & 0,87 \\
\hline
\end{tabular}

\subsubsection{Efeito do broqueamento ( $\left.k_{2}\right)$}

$\mathrm{O}$ efeito deletério do broqueamento deve ser considerado em todos os casos.

Para levar em conta o efeito do broqueamento, emprega-se o coeficiente $\mathrm{k}_{2}$ que pode ser admitido igual a $\mathbf{k}_{2}=1,06$ para todos os casos.

\subsubsection{Direção da extração e ensaio em relação ao lançamento do concreto $\left(k_{3}\right)$}

Cabe ao responsável pela extração informar ao Laboratório de ensaio sobre a direção de extração com relação à direção do lançamento do concreto.

Para extrações realizadas no sentido ortogonal ao lançamento (como em geral ocorre com pilares, cortinas e paredes moldados no local), $\mathrm{k}_{3}$ $=1,02$.

Para extrações realizadas no mesmo sentido do lançamento (como lajes), $\mathrm{k}_{3}=1,00$.

Esta correção do resultado de ensaio é aplicável a todos os casos.

\subsubsection{Efeito da umidade do testemunho no ensaio $\left(\mathbf{k}_{4}\right)$}

Para testemunhos ensaiados a seco, utilizar o coeficiente $\mathrm{k}_{4}=0,95$.
Para testemunhos ensaiados saturados, utilizar o coeficiente $\mathrm{k}_{4}=1,00$.

Esta correção deve ser aplicada ao resultado de ruptura e informada no relatório do ensaio e é aplicável a todos os casos.

\subsubsection{Efeito do adensamento ( $\left.\mathrm{k}_{5}\right)$}

Para fins de correção das deficiências de adensamento pode ser admitido que a cada $1 \%$ a mais de volume de vazios no testemunho, em relação ao índice ou volume de vazios do concreto fresco original adensado, pode haver uma perda de $5 \%$ da resistência à compressão do concreto endurecido.

Para fins de aplicar este coeficiente de correção $\left(\mathrm{k}_{5}\right)$, que só se aplica a casos excepcionais, o volume ou índice de vazios do concreto do testemunho deve estar acima de $2,5 \%$ e ainda superar em $1 \%$ ou mais o volume de vazios do concreto fresco adensado original.

\subsubsection{Efeito da cura ( $\left.k_{6}\right)$}

Para fins da correção das deficiências de cura, pois na obra, em geral, a cura é inferior à cura do corpo de prova moldado e mantido no laboratório em condições ideais, onde se recomenda utilizar o coeficiente $\mathrm{k}_{6}$ que só se aplica a casos excepcionais.

Cura submersa ou saturada, do concreto na obra, com UR $>95 \% \rightarrow$ utilizar $\mathrm{k}_{6}=1,00$.

Cura a seco, do concreto na obra, com UR variando de $60 \%$ a $95 \%$, sob temperatura $<32^{\circ}$ $\mathrm{C}$ e com vento até $20 \mathrm{~km} / \mathrm{h}$, na obra $\rightarrow$ utilizar $\mathrm{k}_{6}$ $=1,05$

Cura a seco, do concreto da obra, com UR < $60 \%$, ou sob temperatura $>33^{\circ} \mathrm{C}$, ou sob ventos $>20 \mathrm{~km} / \mathrm{h}$, na obra $\rightarrow$ utilizar $\mathrm{k}_{6}=1,09$.

\section{APRESENTAÇÃO DOS RESULTADOS}

Considerando os coeficientes estabelecidos na seção 4.2, é possível obter a resistência corrigida dos testemunhos extraídos, na idade $\mathrm{j}$ em dias, que corresponde à resistência do concreto à compressão.
Cabe ao laboratório responsável pelo ensaio informar os resultados individuais de cada testemunho, corrigidos pelos coeficientes $\mathrm{k}_{1}$ a k6, obtendo:

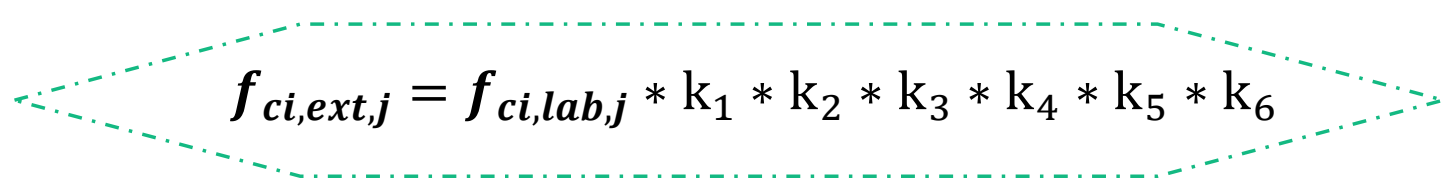


Expresso em MPa, onde a média deve estar no intervalo da ordem de $0,87<f_{c i, l a b, j}<1,25$, e um valor individual não deve superar 1,33.

Para verificar a uniformidade dos resultados, calcular a média aritmética e o desvio padrão da amostra com os resultados individuais corrigidos.

Caso os resultados apresentem uma variabilidade ou coeficiente de variação superior a $\boldsymbol{v}_{\boldsymbol{c}}>25 \%$, estes valores devem ser analisados com mais rigor, pois pode indicar que algum testemunho não faz parte do lote examinado, ou, houve algum erro grosseiro de ensaio.

Nesse caso, pode ser recomendável repetir a extração ou estudar uma nova subdivisão de lotes.

\section{CRITÉRIOS DE ACEITAÇÃO DO CONCRETO}

\subsection{Método simplificado}

Em obras novas, em execução, segundo ACI 318 , independentemente da idade do concreto, corrigindo o $f_{c i, l a b, j}$ apenas com o coeficiente k1, o concreto da estrutura poderá ser aceito, sem maiores estudos, sempre que, para um lote representado por 3 testemunhos:

$\checkmark \quad$ a resistência média dos 3 valores, $\boldsymbol{f}_{\text {ci,ext }, j}$ superar $\rightarrow 0,85 * f_{c k}$ e,

$\checkmark$ qualquer valor individual de $f_{c i, e x t, j}$ superar $\rightarrow 0,75 * f_{c k}$

\subsection{Método dos coeficientes de correção}

Para os casos que requeiram maiores estudos e detalhes, o concreto da estrutura poderá ser aceito sempre que sejam aplicados a cada valor individual de $f_{c i, l a b, j}$ todos os coeficientes de correção pertinentes indicados de $\mathbf{k}_{\mathbf{1}}$ a $\mathbf{k}_{\mathbf{6}}$, obtendo-se os correspondentes valores individuais $f_{c i, e x t, j}$ para cada testemunho:

$$
\boldsymbol{f}_{\boldsymbol{c i}, \boldsymbol{e x t}, \boldsymbol{j}}=\boldsymbol{f}_{\boldsymbol{c i}, \boldsymbol{l a b}, \boldsymbol{j}} * \mathrm{k}_{1} * \mathrm{k}_{2} * \mathrm{k}_{3} * \mathrm{k}_{4} * \mathrm{k}_{5} * \mathrm{k}_{6}=:=
$$

Para cada lote, de uma mesma betonada ou de uma mesma região identificada como crítica, representado por, no máximo, 6 testemunhos (pode ser apenas 1), com $\boldsymbol{v}_{\boldsymbol{c}}<25 \%$, o concreto deve ser aceito sempre que o valor mais alto do lote for igual ou superior ao $f_{c k}$ de projeto, qualquer que seja a idade.

Observar que caso ocorram valores individuais muito baixos ( $<0,75$ do valor mais alto do lote), há fortes indícios de que a execução da concretagem foi mal feita e há problemas executivos que devem ser corrigidos, quem sabe até com reforços ou substituições localizadas do concreto.

A resistência à compressão potencial do concreto nesse lote, comparável à dos corpos de prova moldados, corresponde ao valor mais alto por conceito: não há operação de obra que aumente a resistência do concreto após entregue. Ao contrário, todos os pequenos e grandes erros de obra e de ensaio só reduzem a resistência verdadeira do concreto.

\subsection{Verificação da segurança estrutural}

Sempre e quando o concreto da estrutura não atender os critérios expressos em 6.1 e 6.2, ou seja, não atendeu o $\boldsymbol{f}_{\boldsymbol{c}}$ de projeto, deve ser realizada uma verificação estrutural tomando-se como novo $f_{c k}$ o valor mínimo obtido em 6.1 ou com o máximo obtido em 6.2.

A avaliação dos valores a serem considerados para comprovação da segurança estrutural deve ser realizada por profissional habilitado para tal. Nesta verificação, a resistência de projeto $f_{c d}$ a ser usada na verificação da segurança da estrutura deve ser calculada, utilizando-se uma redução de $10 \%$ no coeficiente de minoração da resistência característica do concreto à compressão, ou seja, reduzir $\gamma_{c}$ de $10 \%$.

Em geral, não há necessidade nem razão técnica 
para regredir a resistência do concreto a 28 dias. A resistência do concreto, sem carga, pode aumentar com a idade por efeito das reações de hidratação dos cimentos, uns mais, outros menos, em função também das condições de cura e das condições ambientais localizadas de umidade e temperatura.

Mas a resistência dos concretos também pode reduzir com a idade, quando está sob carga, por efeito das chamadas cargas de longa duração, na realidade, qualquer carga significativa que perdure atuando por tempo superior a 15 minutos. Caso seja necessário considerar um eventual crescimento por conta da hidratação do cimento, pode ser utilizado o inverso do modelo clássico e consagrado de previsão do crescimento da resistência do concreto. Considerando que os concretos nas estruturas não estão sob as condições ideais de temperatura e cura úmida, além de muitas vezes não terem sido corretamente lançados e adensados, recomenda-se ser conservador na previsão do crescimento da resistência in loco, adotando o coeficiente exponencial de $\beta=0,17$.

Assim, procedendo a uma eventual regressão a 28 dias, por conta da hidratação dos cimentos, poderia utilizar a seguinte expressão:

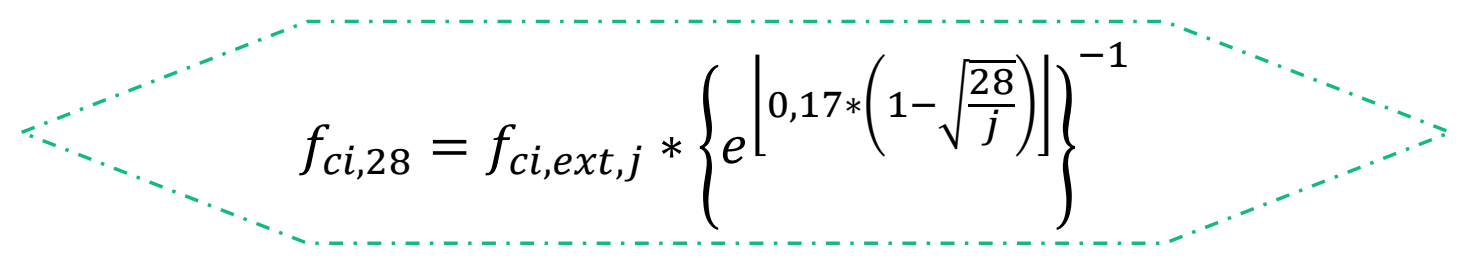

Caso seja necessário considerar o efeito negativo das cargas de longa duração, pode ser utilizado o inverso do modelo clássico e consagrado de previsão da redução da resistência do concreto com o período de tempo da carga de longa duração, ou seja, da carga mantida.

Assim, procedendo a uma eventual regressão a 28 dias, por conta das cargas mantidas, poderia utilizar esta expressão:

$f_{c i, 28}=f_{c i, e x t, j} *\{0,96-0,12 * \sqrt[4]{\ln [72(j-28)]}\}^{-1} \ldots$

Caso não se comprove a segurança estrutural a partir dos resultados dos testemunhos extraídos, podem ser realizadas novas avaliações com outras metodologias apropriadas, como reduzir outros coeficientes de minoração, reavaliar cargas e ações, reavaliar geometria dos elementos, prova de carga ou qualquer outro ensaio especial, em comum acordo entre as partes envolvidas, para aprimorar a análise da segurança estrutural e verificar a possibilidade de aceitação da estrutura.

\subsection{Não conformidade final}

Constatada a não conformidade final de parte ou do todo da estrutura, deve ser escolhida e aplicada uma das seguintes alternativas:

a) determinar as restrições de uso da estrutura;

b) providenciar o projeto de reforço;

c) decidir pela demolição parcial ou total da estrutura.

\section{FLUXOGRAMA DO PROCEDIMENTO}

O fluxograma da Fig. 8 ilustra as etapas necessárias para obtenção da resistência à compressão do concreto em estruturas existentes, equivalente à resistência característica do concreto à compressão que deve ser utilizada na verificação da segurança estrutural. 


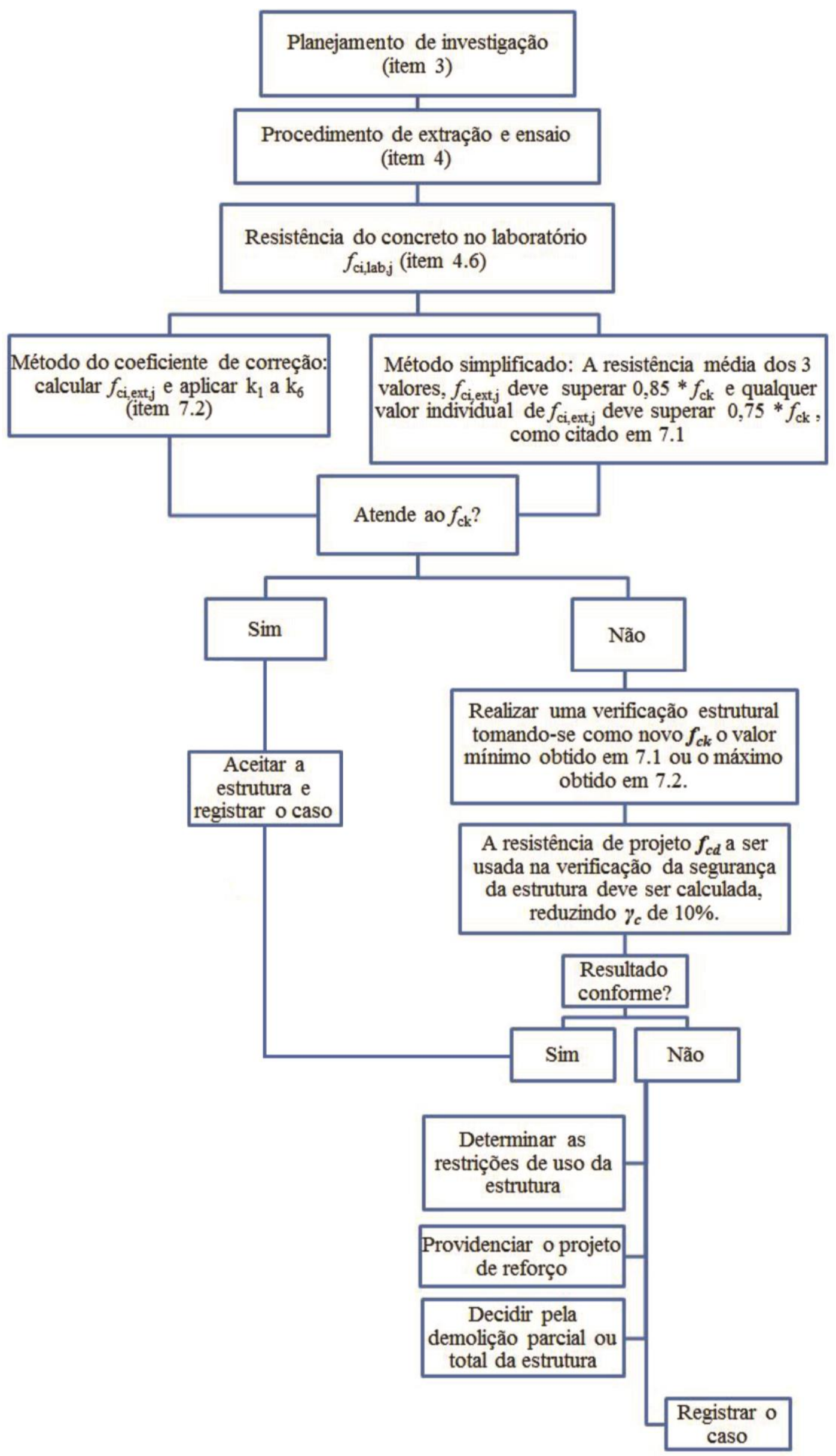

Figura 8. Procedimento para a obtenção da resistência à compressão do concreto em estruturas existentes 


\section{BIBLIOGRAFÍA PARA APROFUNDAMENTO DO TEMA}

1. ABNT NBR 12655. Concreto de cimento Portland - Preparo, controle e recebimento Procedimento;

2. ABNT NBR 14931. Execução de estruturas de concreto - Procedimento;

3. ABNT NBR 15146-1. Controle tecnológico de concreto - Qualificação pessoal;

4. ABNT NBR 5738. Concreto - Procedimento para moldagem e cura de corpos de prova;

5. ABNT NBR 5739. Concreto - Ensaios de compressão de corpos de prova cilíndricos;

6. ABNT NBR 6118. Projeto de estruturas de concreto - Procedimento;

7. ABNT NBR 7584. Concreto endurecido - Avaliação da dureza superficial pelo esclerômetro de reflexão;

8. ABNT NBR 7680. Concreto- Extração, preparo, ensaio e análise de testemunhos de estruturas de concreto;

9. ABNT NBR 8681: Ações e Segurança nas Estruturas. Procedimento.

10. ABNT NBR 8802. Concreto endurecido - Determinação da velocidade de propagação de onda ultrassônica;

11. ABNT NBR 9778. Argamassa e concreto endurecidos. Determinação da absorção de água, índice de vazios e massa específica

12. ABNT NBR NM 33: Amostragem de concreto fresco. Método de ensaio.

13. ABNT NBR NM 67: Concreto. Determinação da consistência pelo abatimento do tronco de cone. Método de Ensaio.

14. ACI 201.1R-08: Guide for Conducting a Visual Inspection of Concrete in Service.

15. ACI 214: Recommended practice for evaluation of compression test results of field concrete.

16. ACI 214.4R. Guide for obtaining cores and interpreting compressive strength results.

17. ACI 228.2R. Nondestructive Test Methods for evaluation of Concrete in Structures.

18. ACI 318M. Building Code Requirements for Structural Concrete.

19. ACI 364. Guide for Evaluation of Concrete Structures before Rehabilitation.

20. ACI 437R. Strength Evaluation of Existing Concrete Buildings.

21. ASTM C 192: Standard Practice for Making and Curing Concrete Test Specimens in the Laboratory;

22. ASTM C 642 : Standard Test Method for Density, Absorption, and Voids in Hardened Concrete;

23. ASTM C39: Standard Test Method for Compressive Strength of Cylindrical Concrete Specimens;

24. ASTM C42. Standard Test Method for Obtaining and Testing Drilled Cores and Sawed;

25. ASTM C805: Standard Test Method for Rebound Number of Hardened Concrete;

26. ASTM E 494 Standard Practice for Measuring Ultrasonic Velocity in Materials;

27. ASTM. C31: Standard Practice for Making and Curing Concrete Test Specimens in the Field.

28. BARTLETT, F. M.; MACGREGOR, J. G. Equivalent Specified Concrete Strength from Core Test Data. ACI, Concrete International, v.17, n. 3, p.52-8, Mar. 1995.

29. BS 1881 204: Testing Concrete. Recommendations on the use of electromagnetic covermeters. London: BSI, 1988

30. BS 1881. Testing concrete method or determination of the compressive strength of concrete cores

31. CEB-FIP Model Code 90. Design Code. Bulletin d'Information 213/214, Lausanne: CEB, May 1993.

32. CEB. General Principles on Reliability for Structures. Lausanne: CEB, Bulletin 191, 1988.

33. CEN. EN 13791: Assessment of Concrete Compressive Strength in Structures or in Structural Elements.

34. CEN. ENV 13670-1: Execution of Concrete Structures

35. CEN. EUROCODE 2. EN 1992. Design of Concrete Structures. General Rules for Buildings. 
36. CREMONINI, R. A. Análise de Estruturas Acabadas: Contribuição para a Determinação da Relação entre as Resistências Potencial e Efetiva do Concreto. São Paulo: USP, 1994. PCC.EP.USP Tese de Doutorado em Engenharia

37. EN 12390. Testing hardened concrete - Part 4: Compressive strength — Specification for testing machines;

38. EN 206. Concrete. Specification, performance, production and conformity;

39. fib. Model Code 2010. Draft Model Code. March 2010. Lausanne: fib, bulletin 55, v.1

40. fib. Model Code for Service Life Design. Lausanne: fib, bulletin 34, 2006.

41. fib. Monitoring and Safety Evaluation of Existing Concrete Structures. State-of-art Report. Lausanne: fib, 2003. Bulletin22, 304 p.

42. fib. Textbook on Behavior, Design and Performance. Structural Concrete. Lausanne, fib, bulletin 54, 2010.

43. FUSCO, P. B. A influência da variabilidade da resistência do cimento na variabilidade da resistência do concreto. In: Seminário sobre Controle da Resistência do Concreto, 1979, São Paulo. Anais... São Paulo: IBRACON, 1979.

44. HELENE, Paulo. Avaliação da Resistência à Compressão de Estruturas Através de Testemunhos Cilíndricos de Concreto. In: Simpósio sobre Normalização de Cimento, Concreto e Agregados, 1980, São Paulo. Anais... São Paulo: ABNT, CB-18 Comitê Brasileiro de Cimento, Concreto e Agregados, 1980. 33 p.

45. HELENE, Paulo. Controle de Qualidade do Concreto. São Paulo: USP, 1981. 150 p. PCC.EP.USP Dissertação de Mestrado em Engenharia

46. HELENE, Paulo. Concreto Endurecido. Avaliação da Dureza Superficial pelo Esclerômetro de Reflexão. In: Simpósio sobre Normalização de Cimento, Concreto e Agregados, 1983, São Paulo. Anais... São Paulo: ABNT, CB-18 Comitê Brasileiro de Cimento, Concreto e Agregados, 1983. 28 p.

47. HELENE, Paulo. Resistência do Concreto sob Carga Mantida e a Idade de Estimativa da Resistência Característica. In: Simpósio EPUSP sobre Estruturas de Concreto, 3, dez. 1993, São Paulo. Anais... São Paulo: EPUSP, 1993, p. 271-282

48. HELENE, Paulo. Contribuição à Análise da Resistência do Concreto em Estruturas Existentes para fins de Avaliação da Segurança. Revista Construindo, Fumec, Jan/Jul 2012, vol. 4, p. 3248 [http://www.phd.eng.br/wp-content/uploads/2014/06/ar118.pdf]

49. HELENE, Paulo. Contribuição à análise da resistência do concreto em estruturas existentes para fins de avaliação da segurança. São Paulo, ABECE Informa, ano 16, n. 90, Mar.Abr., 2012. p.16-23 [http://www.phd.eng.br/wp-content/uploads/2014/06/AR109.pdf]

50. HELENE, Paulo; PACHECO, Jéssika. Entendendo o Concreto - Controle da Resistência do Concreto $-1^{a}$ parte. Revista Concreto \& Construções, Ibracon, ano XL, n 69 , Jan/Mar 2013, p.75-81 [http://www.phd.eng.br/wp-content/uploads/2014/06/ar121.pdf]

51. HELENE, Paulo; PACHECO, Jéssika. Entendendo o Concreto - Controle da Resistência do Concreto $-2^{a}$ parte. Revista Concreto \& Construções, Ibracon, ano XLI, nº 40, Abr/Jun, 2013. p. 90-98. [http://www.phd.eng.br/wp-content/uploads/2014/06/ar125.pdf]

52. HELENE, Paulo; CARVALHO, Mariana; COUTO, Douglas; BILESKY, Pedro. Análise Crítica do Novo Texto da ABNT NBR 7680-1:2015. 57 Congresso Brasileiro do Concreto, 2015, Bonito/MS, 2015. [http://www.phd.eng.br/wp-content/uploads/2015/11/57CBC0159.pdf]

53. HELENE, P.; COUTO, D.; CARVALHO, M.; CINTRA, A. Estruturas de concreto. Contribuição à análise da segurança em estruturas existentes. Revista IBRACON de Estruturas e Materiais. Vol. 8, Num.3, Jun 2015,p. 365-389 (com discussão) [http://www.phd.eng.br/wpcontent/uploads/2015/10/merged-5.pdf]

54. ISO 13822: Bases for Design Structures. Assessment of Existing Structures.

55. ISO 1920-4. Testing of concrete - Part 4: Strength of hardened concrete;

56. ISO 1920-5. Testing of concrete - Part 5: Properties of hardened concrete other than strength;

57. ISO 1920-6. Testing of concrete - Part6 : Sampling, preparing and testing of concrete cores;

58. ISO 22111. Bases for Design of Structures. General Requirements.

59. ISO 22966. Execution of concrete structures 
60. ISO 2394. General Principles on Reliability for Structures. Genebra: ISO, 2010.

61. JOINT COMMITTEE CEB-CIB-FIP-RILEM. Recommended Principles for the Control of Quality and the Judgement of Acceptability of Concrete. Monografia n. 326. Madri: Instituto Eduardo Torroja, Abr. 1975. 105 p.

62. JOINT COMMITTEE ON STRUCTURAL SAFETY JCSS. Probabilistic Assessment of Existing Structures. Bagneux: RILEM, Jan. 2001.

63. LANIKOVÁ I. et al. An economical design of concrete structures using the fully probabilistic approach (in Czech), Soudniinzenyrstvi, 2010, Vol. 21, No. 1, p. 48-55

64. LINIERS, A. D. Análisis de la Influencia de algunas Variables en la Extracción y Ensayo a Compresión de Probetas Testigos de Hormigón. Madri, Instituto Eduardo Torroja. Informes de la Construcción, n. 266, p. 65-79, 1974.

65. MAYNARD, D. P.; DAVIS, S. G. The Strength of "in situ” Concrete. The Structural Engineer, London, v. 52, n. 10, p. 369-74, Oct. 1974.

66. MCINTOSH, J. D. Concrete and statistics. London: CR Books, 1963.

67. MESEGUER, A. G.. Control de la Calidad. In: Colloque Européen sur le Contrôle de la Qualité dans la Construction,1, 1976, Madrid. Compterendus... European Organizaton for Quality Control EOQC, 1976. p. 361-3.

68. PETERSONS, N. Recommendations for Estimation of Quality of Concrete in Finished Structures. Stockolm. Materials et Constructions, v. 4, n. 24, p. 379-97, 1971.

69. RUIZ, J. C. La influencia de las variaciones resistentes de los materiales y de las variaciones dimensionales de las piezas de hormigón armado sobre su capacidad resistente. Madrid, Instituto Eduardo Torroja, Monografia 324, 1975.

70. RÜSCH, H. Researches toward a general flexural theory for structural concrete. Journal of the American Concrete Institute, Detroit, v. 57, p. 1-28, jul. 1960.

71. VIEIRA FILHO, J. O. Avaliação da Resistência à Compressão do Concreto através de Testemunhos Extraídos: Contribuição à Estimativa do Coeficiente de Correção devido aos Efeitos do Broqueamento. São Paulo: USP, 2007. PCC.EP.USP Tese de Doutorado em Engenharia 